\title{
Prophetic Ethics Of Banyumas Women In Kubah Novels By Ahmad Tohari As A Teaching Materials And Media For Strengthening Character
}

\author{
$1^{\text {st }}$ Septi Yulisetiani \\ Sebelas Maret University (UNS) \\ Surakarta, Indonesia \\ riyadisugeng419@gmail.com
}

\author{
$2^{\text {nd }}$ Sarwiji Suwandi Suyitno \\ Sebelas Maret University (UNS) \\ Surakarta, Indonesia \\ riyadisugeng419@gmail.com
}

\author{
$3^{\text {rd }}$ Slamet Subiyantoro \\ Sebelas Maret University (UNS) \\ Surakarta, Indonesia \\ riyadisugeng419@gmail.com
}

\begin{abstract}
This article reveals the Banyumas women's prophetic ethics in the Kubah novels written by Ahmad Tohari. The source of the data in this research is the literature text in the Kubah novels. Kubah novels contain a narrative of the life story of a female character who lives in Banyumas Regency, Central Java, Indonesia. The research method used in the novel Kubah is a critical discourse analysis which shows the existence of prophetic ethics of female characters. Prophetic ethics consists of ethics of transcendence, ethics of liberation, and ethics of humanization. Banyumas women's prophetic ethics in the Kubah novels can be a good example for readers. In strengthening noble character, prophetic ethics can form human beings who are obedient to God, care for their fellow humans and the universe. Thus, the novel Kubah by Ahmad Tohari can be used as contextual teaching material and a medium for strengthening noble characters.
\end{abstract}

Keywords-Banyumas Women, Noble Characters, Prophetic Ethics, Teaching Materials

\section{INTRODUCTION}

The phenomenon of dehumanization increases and worries the public. This can be known from various mass media that broadcast news of crime, corruption committed by state officials, acts of natural destruction that cause disasters, and so on. This phenomenon is caused by human behavior that is not based on common sense, values, and norms. Humans are very selfish, have no concern for other human beings, other living beings and the nature that surrounds their lives [1]

At present, dehumanization has occurred in various aspects. Among them are ideological, economic, political and morals. As a result, there are many people who are poor spiritual, materialistic, individualistic, desire more to be in power, willingness to seek personal gain, and apathetic. This behavior can be reduced by the awareness of self-control in dealing with various life problems. Self-control can minimize dehumanization phenomenon. [2].

This publication sponsored by LPDP (Lembaga Pengelola Dana Pendidikan ) Schoolarships , Indonesia
Self-control measures can be carried out by strengthening prophetic ethics in individuals. Prophetic ethics includes humanization ethics, liberation ethics, and transcendence ethics [1], [3], [4], [5]. Humanization can be interpreted as behavior based on efforts to revive a sense of pre-humanity towards others. Liberation is a hard work to realize the ideals of a free human being, both individually and in groups and reject restrictions. Whereas transcendence is an awareness of God's presence towards whatever meaning transcends humanity [6], [7], [8], [9]. These three aspects are the foundation of prophetic ethics that can balance human life. Thus, it can create an ethical human being who has the freedom to determine the attitude of life with full tolerance, has concern for fellow human beings, and the surrounding environment. Noble people will carry out all activities with the awareness of carrying out God's commands and away from God's prohibitions.

Understanding of prophetic ethics can be done through prophetic education through the scope of family, school, and society. In the scope of schools, prophetic education seeks to integrate an educational system that concentrates on moral values, and religious values with a modern education system that develops human values. Prophetic education was developed to apply prophetic ethics.

The implementation of prophetic education can be done with literary works. The implementers are through literary learning and other learning that utilize literary works as teaching materials and learning media. For this reason, research on prophetic literature is important and documented. The work of prophetic literature can be used as teaching material and a medium for strengthening noble characters. This is in accordance with the function of literature as a means to educate characters following the values of life [10]. Literary works are not just imaginary constructions, but the results of thought on socio-cultural conditions that are strictly related to life, so it can strengthen the human experience [11], [12]. 
Prophetic literature can construct the character of the nation's generation that excels in the intellectual and noble character. Prophetic literature is called worship literature and pure literature. Literature of worship means expression of the appreciation of religious values; whereas pure literature means the expression of the catch of objective and universal reality. Prophetic literature can be one of the prizes for social, political, economic, legal and cultural turmoil. The beauty of prophetic literature lies in its function to expand the human mind, arouse divine and humanity awareness [13], [14].

One of literary work that contains prophetic values is the Kubah novels by Ahmad Tohari. Ahmad Tohari's writting styles is always related to Islamic tradition of Islamic Boarding School. Religious values are the prophetic core of Ahmad Tohari's literary works. The novel narrates the lives of female characters with the background of the Banyumas community. Women's characters in the Kubah novels have a harmonious life. Harmony is realized with prophetic ethics which is used as a guide in life. Banyumas women's prophetic ethics in Kubah novels can be used as teaching materials and media for character strengthening.

\section{THE PROPHETIC ETHIC OF BANYUMAS WOMEN}

First, Prophetic ethics is a rule based on prophetic values: the value of transcendence, the value of liberation, and the value of humanization. Novel Kubah tells the story of the female character of Banyumas. These included Marni, Bu Haji Bakir, and Tini. They were narrated in the story, as figures who applied prophetic ethics as a foundation in life.

Marni figures in the Kubah novels are told as figures who have prophetic ethics in dealing with life's problems. All problems believed by Marni as a destiny of life from God. When the problem that occurred to Marni is going difficult, then he trusts God with prostration, prayer, and asking for help. This story fragment is a manifestation of the ethics of Marni character transcendence.

Di kamar pesalatan Marni berusaha mencari kesadaran tertinggi agar bisa berdekat-dekat dengan Tuhan. Ia bersimpuh dan merasa begitu kecil dan lemah. Namun dalam kesadaran akan kelemahan itulah Marni menemukan sikap yang akan ditempuhnya. "Besok aku akan bertawakal; membiarkan apa yang harus terjadi, terjadilah [7].

In the praying room, Marni tried to find the highest awareness in order to get close to God. She knelt and felt so small and weak. But in the awareness of the weakness, Marni found the attitude she would take. "Tomorrow I will trust; let what must happen, it will happen [7].

In the above quote, it appears that Marni has divine awareness. Marni realized that all help came from God. So marni put their trust in God. As a Muslim, Marni believed in the word of God about trustworthy orders. One of them is found in Al-Quran Surat Al-Maidah 23. In the verse it is stated that the trust is an act committed by a believer.
Transcendence awareness forms Marni to obey God's commands. Obedience to God made her a wise person in her attitude towards fellow humans. A wise attitude between humans is a form of humanization ethics. Marni also becomes a figure who has the freedom to decide her best way of life. Human freedom carried out with consideration of goodness according to God and fellow human beings are the application of ethical liberation. Marni's independence is seen in the fragment of the story which tells the story of Marni and her relatives. When Marni's sibling force her to remarry, Marni had the right to make her best decision.

Marni tidak menghiraukan bujukan sanak-saudara yang menghendaki dia menikah lagi [15]. Tahun 1971

Marni mengubah pendirianya. Ia mengikuti saran sanak famili. Maka sehelai surat ditulis untuk suaminya. Marni mengambil keputusan kawin lagi [15].

Marni ignored the persuasion from her relatives who wanted her to remarry [15]. In 1971 Marni changed her decision. She followed the advice of relatives. Then a letter was written for her husband. Marni took the decision to remarry [15].

First, she chose to keep waiting for her husband to out of the prison for political prisoners. With the consequences, she must be struggling to support her children. Second, she chose to divorce, after seeing the condition of her children who needed a father figure in their lives. Marni finally remarried for the survival of her children. The wisdom that can be taken from the Marni figure is the determination to solve various life problems. Marni figures are increasingly devoted to worship and wise towards others.

Women character who have prophetic ethics other than Marni are Bu Bakri. In Kubah novels, Bu Bakri's character is described as a rich person who remains friendly to everyone. This figure has a transcendent awareness that only faith can distinguish one human being from another. Finally, Bu Bakri wanted to hang out with the poor Tini figure. Bu Bakri who does not insult the poor can be an example to bring about a harmonious life.

“...Aku berdampingan dengan Bu Haji Bakir, nenek Jabir. Wah, malu..." "Beliau mau bicara denganmu?"

"Mau. Malah lebih dari itu. Aku diajak singgah ke rumahnya. Beliau memuji bacaan Quran-ku...[15]

"... I sat side by side with Mrs. Haji Bakir, Grandma.

Wow, I'm embarrassed ... "" She talked to you? "" Yes,

She did. Even more than that. I was invited to visit his

house. He praised my Quran recitation ... [15]

Tini figures have a good personality. He is portrayed as a devout and wise person in dealing with problems. Among them is the problem from her friends who bullied him as stepchildren and have bad fathers who are imprisoned as political prisoners.

Tini remains wise to hang out with friends who mock, hang out with fathers who are considered evil. Tini doesn't have revenge. The following quote shows the attitude of Tini's character. 
Rasa rendah diri itu tumbuh ketika Tini mulai mengerti bahwa Parta bukan ayah kandungnya. Pada saat yang sama, ia tahu dimana dan bagaimana ayahnya yang sejati. Orang-orang di sekelilingnya sering memberi gambaran buruk tentang para tahanan politik [15]. "Jadi ayah pasti pulang ya, bu? Jadi aku punya ayah yang sebenarnya ya, bu? Aku sangat ingin melihat ayah [15].

This inferiority complex grew when Tini began to understand that Parta was not her biological father. At the same time, he knows where and how his true father is. People around him often give a bad picture of political prisoners [15]. "So daddy must go home, ma'am? So I have a real father, ma'am? I really want to see father [15].

The prophetic message that can be taken from Tini's character is that fortitude is the key to happiness. Steadfastness will make people obey God. Steadfastly makes people sincere and easy to forgive the mistakes of others. Humans live without revenge. Prophetic ethics possessed by female characters in the Kubah novels is interesting to be used as teaching materials and character strengthening media.

\section{TEACHING MATERIAL AND CHARACTER STRENGTHENING MEDIA}

Teaching materials have an essential role in the success of a learning. The quality of teaching materials can influence the experience and knowledge gained by students. The choice of teaching materials must be adapted to the character of the students, the condition of the place of learning and the situation of the learning process. The preparation of teaching materials serves to provide teaching materials that are in accordance with the needs of students, facilitate student learning, and facilitate teachers in carrying out learning [16], [17], [18].

Ideal learning is learning that collaborates with understanding theory and its relevance in life [19]. Learning requires authentic and contextual teaching materials. Authentic teaching materials can provide information about life events. Contextual teaching materials contain events that are close to students. Teaching materials that meet authentic and contextual criteria are literary works.

Literary work contains a portrait of life in a society. Literary readers can find narratives of stories that have similarities with real life. Humans are the same as the characters, the setting is the same as the place, the plot is the same as the time and so on. In real life, humans have various activities in life. In literary works, authors describe figures who represent humans in real life. These figures live somewhere and have multiple problems that are the same as the problems of human life. For this reason, fictional stories in a literary work can be used as authentic and contextual teaching material. Learners can learn through the stories of characters found in literary texts.
As part of the art, literary works are built with language as the main media. Literary work contains a lot of ideas, complex structures, and is conveyed indirectly with beautiful figurative language. To get a comprehensive meaning, literary works need to be interpreted so as to clarify the message the author wants to convey [20].

Literary learning is expected to foster student's appreciation of literary works [21]. The purpose of literary learning is generally emphasized in order to realize the ability of students to adequately appreciate literature [22]. Literary appreciation activities relate to the introduction efforts, the cultivation of cultural values, local wisdom, and character strengthening. For this reason, literary works can be used as a medium for character reinforcement. The aesthetic and poetic values of literary works are believed to be able to pump and build human character. Moral values are internalized in students through literary learning [23]. Prophetic ethics of Banyumas women in the Kubah novels written by Ahmad Tohari can be used as teaching materials and media for character development.

\section{AFTERWORD}

Kubah novels by Ahmad Tohari contains the prophetic ethics of women in Banyumas. The story can be used as teaching materials and media for strengthening noble character. Prophetic ethics can be a guide in living life with faith in God, love for fellow human beings and nature. A person who has prophetic ethics will obey God's commands, be wise to fellow human beings, and preserve the environment. Researches on literary works that contain prophetic ethics were necessary to be continued, in order to reveal essential messages conveyed by the author in literary texts. The results of literary research are documents that can be used as teaching materials and media to strengthening noble characters.

\section{References}

[1] Kuntowijoyo. Maklumat Sastra Profetik. Yogyakarta: Multi Presindo, 2013.

[2] Santana, M. A \& Kumala, I. D. “Agresivitas dan Kontrol Diri pada Remaja di Banda Aceh", in The Jurnal Sains Psikologi, 6, (2), pp. 51-11, 2017.

[3] Branch, R. G. "Genesis 20: A literary template for the prophetic tradition". International Journal of Applied Linguistics \& Literature. Vol 38 (2). Pp. 217-234, 2004.

[4] Yaman, H. "Prophetic Value niche in the virtuous city: The concept of hikmah in early Islamic thought". Journals Intellectual Discourse. 22 (2). 236-239, 2004

[5] Ahmad, S. "The Concept of Islamic Work Ethic: An Analysis of Some Salient Points in the Prophetic Tradition". International Journal of Business and Social Science. Vol 3 (2). Pp 55-67, 2012.

[6] Sofan, M. Pendidikan Berparadigma Profetik: Upaya Konstruktif Membongkar Dikotomi Sistem Pendidikan Islam. Yogyakarta: Ircisod, 2004. 
[7] Trianton, T. Estetika Profetik Ahmad Tohari dalam Khazanah Budaya Cablaka. Jurnal Kajian Islam dan Budaya. 11, (2), Pp. 211-226, 2013.

[8] Klingbell, M. G. "Creation in The Prophetic Literature of The Old Testament: An Intertextual Approach". Journals of the Advertist Theological Society. 20 (2), 118-131, 2009.

[9] Sheldon H. B. "Religious Educational Values in Prophetic Literature". Journals The Religious Educational Association. Vol. 41 (2). Pp. 211-221, 2016.

[10] Pramuki, B. E. "Peran Sastra sebagai Sarana pembentuk Karakter Bangsa". Proceeding Seminar Internasional. Pendidikan Bahasa Indonesia, Universitas Sebelas Maret Surakarta. pp. 141-145, 2013.

[11] Barnet, B. An Introduction to Literature: Fiction, Poetry, Drama. Boston: Little Brown And Company, 1967.

[12] Tatlow, A. (2000). Comparative Literature as Textual Antropology. Jurnal Prude. 2 (4), 2-7.

[13] Hadi. A. W. M. Hermeneutika, Estetika, Dan Religiusitas. Yogyakarta: Matahari, 2004.

[14] Classens, L. J. M. "Human dignity in the prophetic traditions: Upholding human worth in a context of dehumanisation". 31(1), 65-74, 2009.

[15] Tohari, A. Kubah. Jakarta: Gramedia, 2017.

[16] Suwandi, S. Jubagyo, H. \& Rohmadi, M. "Pendidikan Multikultural dalam Buku Ajar Bahasa dan Sastra
Indonesia untuk Siswa Sekolah Menengah Pertama di Surakarta". Jurnal Ilmiah Kebahasaan dan Kesastraan: Widyaparwa. 41. (1). Pp. 29-39, 2013.

[17] Amri, S. \& Ahmadi K. Konstruksi Pengembangan Pembelajaran Pengaruhnya terhadap Mekanisme dan Praktik Kurikulum. Jakarta: Prestasi Pustaka, 2010.

[18] Muslich, M. Text Book Writing. Yogyakarta: Ar-Russ Media, 2010.

[19] Depdiknas. Panduan Pengembangan Bahan Ajar. Jakarta: Depdiknas, 2008.

[20] Trianton, T. \& Yulisetiani, S. Literature in Multiliteracy Perspective. Proceding International Conference. Universitas Muhammadiyah Purwokerto, 2017.

[21] Yulisetiani, S. Kearifan Lokal dalam Kumpulan Cerpen Kompas 2012 sebagai Bahan Ajar Kontekstual. Prosiding Seminar Nasional Adobsi, 2015.

[22] Yulisetiani, S. Sastra Lokal sebagai Materi Ajar Kontekstual. Prosiding Seminar Internasional. Universitas Sebelas Maret Surakarta, 2013.

[23] Trianton, T. "Nilai Pendidikan Karakter Berbasis Kearifan Lokal dalam Film Indie Banyumas". Jurnal Khazanah Pendidikan. Vol 2 (1), 2013. 